TURIZAM

Volume 17, Issue 1

18-28 (2013)

\title{
Film Tourism: A Contemporary Resource for Promoting Serbia
}

\author{
Dejan Berić*, Milutin Kovačević*, Karolina Simat*, Sanja Božić* \\ Received: January 2013 | Accepted: March 2013
}

\begin{abstract}
Studies of the relationships between film, TV and tourism are relatively new, and in development mainly since the early 1990s. Leisure activities such as watching films as well as traveling are ways to escape. Both provide temporary relief from the real world. Contemporary tourism industry itself is very competitive and many new destinations are trying to attract the tourists to their destinations. Film can provide knowledge of certain aspects of the country such as nature, culture and people which result in the construction of the attitudes towards the country. An interest in the nation and its positive image can eventually lead to an actual visit to the country. Serbia offers a range of scenery that can serve diverse location needs from villages to rivers, mountains and forests. The country's unique architecture from Ottoman and Habsburg to Socialist period structures and from Roman and Medieval to contemporary urban is offering rich, distinct backdrops for a variety of productions. This paper investigates the film tourism phenomenon by reviewing previous research and practices (in several countries, including Serbia) to highlight the benefits of film in promoting toursit products.
\end{abstract}

Keywords: film, tourism, Serbia, destinations.

\section{Introduction}

Today, tourists are more experienced and more selective in their choice of holidays, in terms of destination and activities. It can no longer be counted on the fact that guests will visit e.g. Serbia just because this is what they usually do. Contemporary tourists will via the internet create their own experiences and holiday packages on the basis of a precise match with their preferences. Hence, the industry will have to find new ways and means to meet the tourists' demands and film tourism represents those novel ways of reaching the audience. (www. northseascreen.eu).

The tourism industry itself is very competitive with many new destinations trying to attract the tourists to their destinations (Rewtrakunphaiboon, 2009). There has been an increasing number of tourists visiting destinations featured through films and television series which are not directly related to tourism promotion campaigns. This phenomenon is

* University of Novi Sad, Faculty of Sciences, Department of Geography, Tourism and Hotel Management, Trg Dositeja Obradovića 3, 21000 Novi Sad, Serbia; Corresponding author: bericdejan@gmail.com 
called film-induced tourism which represents a gateway to new and more intense ways of experiencing destinations.

Film makers are in constant search for suitable locations in natural or urban environment. In most cases the locations have to be pure, idyllic or unique, but in every case sites that are interesting and suitable for movie settings. The sentiments emitted to the spectators, are implied to a significant degree by the action, the heroes and the settings. Thus a strong motive is generated to the spectators to visit the location, in the framework of their conscious or unconscious identification with the movie. This, provided that the settings of movie are in natural or civil environment, constitutes a first class opportunity of the location to be identified as a potential tourist destination (Vagionis and Loumioti, 2OII).

For destinations, films do not only provide short-term tourism revenue to the destination but also long-term prosperity. Additional businesses and services can be created through film tourism that in turn can encourage the extension and strengthening of the visitor season (Hudson and Ritchie, 2006). Both the film industry and the tourist trade make a living from creating experiences. When combining the two approaches, there is potential for considerable synergy - once a destination appears on screen, this creates a wealth of opportunities for the local business community, provided that the relevant players cooperate.

The impact of film tourism is evident in destinations world-wide (Connell and Meyer, 2009), but the study of film tourism is relatively new in tourism research. This paper investigates the phenomenon by reviewing previous research and practices (in several countries, including Serbia) to highlight the benefits of film in promoting toursit products.

\section{Film Tourism Research}

Film tourism has been defined with various terms - „film-induced tourism”, „mediainduced tourism”, „movie-induced tourism”, „cinematographic tourism”, „screen tourism” or even „media pilgrim” seen as a media pilgrimage (Horrigan, 2009).

Busby and Klug (2OOI) have suggested that cinematographic tourist is the tourist that visits a destination or attraction because it appeared in a movie, video or television. Hereafter, Iwashita (20O3) claimed that films, television and literature, are factors which expose the particular characteristics and attractions of a destination and, because of that, can influence the travelling preferences of individuals. Moreover, Macionis (2004) defined film tourism, as a post-modern experience of the tourist in a site, which has been depicted in some form of media. This experience is personalised and unique to each individual, because it depends on his own interpretation of media images. Hudson and Ritchie (2006), suggest that film tourism is the tourism that is generated as a result of the appearance of a destination or attraction in the cinema, video or television.

Studies of the relationships between film, TV and tourism are relatively new, and in development mainly since the early I990s. Schofield (1996) suggested that contemporary tourists' organic images of places are shaped through the vicarious consumption of film and television without the perceptual bias of promotional material. Riley et al. (I998) began to analyse the changes of the visitor number at ten former film sites in United States. Busby \& Klug (2OOI) studied the visitor profiles in Notting Hill, London. Kim and Richardson (2003) analysed how „Before Sunrise“ filmed in Vienna and „Groundhog Day“ filmed in Pennsylvania can influence the viewers' perceptions of a place. Hudson and Ritchie (2006) examined the impact of „Captain Corelli's Mandolin“ on the Island of Cephalonia in Greece. 
Iwashita (2006) surveyed the impact of UK popular cultures on Japanese visitors to UK. Carl et al. (2007) explores the film tourists' motivation, expectation and satisfactions of landscapes of the location of „Lord of the Rings“. Recently, research related to Asian films by Kim et al. (2008) initially investigated the impact of Korean drama series in reducing tension and mistrust between Japan and Korea.

There is also a gap in the research literature with regard to the on-site experiences and consequently there is little understanding of how film tourists perceive, interact and relate to the destination. Macionis and Sparks (2006) state that most film tourists are incidental (i.e. just happen to be at the destination) but increasing evidence, especially from UK research, implies that huge increases in visitors correspond with film and TV showcasing, indicating that the importance of this type of tourism should not be underestimated.

Table 1. Film Tourism Impact in Destinations

\begin{tabular}{|c|c|c|}
\hline FILM / TV SERIES & LOCATION & IMPACT \\
\hline Braveheart & Wallace Monument, Scotland & $300 \%$ increase in visitors year after release \\
\hline Dances with Wolves & Fort Hayes, Kansas & $\begin{array}{l}25 \% \text { increase compared with } 7 \% \text { for } 4 \text { years } \\
\text { before }\end{array}$ \\
\hline Close Encounters of the Third Kind & Devils Tower, Wyoming & $\begin{array}{l}75 \% \text { increase in } 1975,20 \% \text { visit now because of } \\
\text { the film }\end{array}$ \\
\hline Field of Dreams & lowa & $35 \%$ visits in 1991 , steady rise \\
\hline Dallas & Southfork Ranch, Dallas & 500,000 visitors per year \\
\hline Lord of the Rings & New Zealand & $10 \%$ increase every year 1998 to 2003 from UK \\
\hline Steel Magnolias & Louisiana & $48 \%$ increase year after release \\
\hline Last of the Mohicans & Chimney Rock Park, North Carolina & $25 \%$ increase year after release \\
\hline Harry Potter & Various U.K. locations & All locations - increase of $50 \%+$ \\
\hline Mission: Impossible 2 & National parks, Sydney & $200 \%$ increase in 2000 \\
\hline Gorillas in the Mist & Rwanda & 20\% increase in 1998 \\
\hline The Beach & Thailand & $22 \%$ increase-youth market 2000 \\
\hline Four Weddings and a Funeral & The Crown Hotel, Amersham, England & Fully booked for at least 3 years \\
\hline Saving Private Ryan & Normandy, France & $40 \%$ increase - American tourists \\
\hline Pride and Prejudice & Lyme Park; Cheshire, U.K. & $150 \%$ increase in visitors \\
\hline Troy & Canakkale, Turkey & $73 \%$ increase in tourism \\
\hline Captain Corelli's Mandolin & Cephalonai, Greece & $50 \%$ increase over 3 years \\
\hline
\end{tabular}

Source: Horrigan, 2009. (edited from Hudson and Ritchie, 2006)

Presently, there is a growing body of research related to film tourism generally (Beeton, 2005; Connell and Meyer, 2009) which can be classified into five broad categories: (I) the influence of film on the decision to travel; (2) the characteristics and motivations of film tourists; (3) the characteristics and motivations of screen tourists; (4) the impacts of film tourism on visitation numbers and on residents; (5) destination marketing activities related to film tourism. It is beyond the scope of this paper to review all of this literature, however, it is clear from Table I, which summarizes some of the above research, that film and television can have a very positive impact on tourism visits (Hudson and Ritchie, 2006). 


\section{Film Tourism in Practice}

Literature shows that the promotional activities stem mainly from public tourist institutions or private tourist enterprises or in collaboration of both.

Canada and the Bahamas, for example, have engaged Weber Shandwick, one from the most important personalities in public relationships in the world, in order to achieve their region's maximum possible appearance in films. After the terrorist act of IIth September the local organisation of tourism of New York used personalities of sports, movie stars and also the ex-Mayor Rudolf Giuliani for the reinforcement of tourism in the city. (Vagionis and Loumioti, 2OII). The Department for Tourism of Kansas allocates annually I.2 million dollars for the tourist promotion of the State as a film location. The National Council of Tourism of Australia invested some $4 \mathrm{O}$ million dollars in an international advertising campaign based on the film „Australia“, showing the wild beauty of Western Australia. The particular campaign has been the second high budget campaign in national level. The first concerned in the trilogy of „Lord of the Rings“ and the destination New Zealand (Vagionis and Loumioti, 2OII).

In some cases there has been less strategic thinking regarding film content and its affect on consumer perception other than how beautiful their locations look. The danger with this limited perspective is that a destination such as the Cayman Islands could be better known for tax evaders because of a film like „The Firm“ with Tom Cruise than a beautiful, safe and romantic island getaway (Horrigan, 2009).

England is a good example of how film and television has been a blessing on their tourism industry. Approximately 28 million visitors visit Britain each year after viewing the country on the screen (Kim et al., 2008). The Australian Tourism Commission recently collaborated with Disney on 'Finding Nemo', being the first country to promote a destination through an animated film.

Movie maps have been found to be successful as part of film tourism marketing campaigns (Hudson and Ritchie, 2006). They can ease film tourists to trace the locations where the films took place. VisitBritain produced a movie map highlighting over 200 filmed locations across Britain which presented film-related places. These materials have quickly become Visit-Britain most successful printed product. Other destinations that have produced movie maps include United States, Australia, New Zealand and Korea.

Promotion of hotels, guesthouses and dining places featured in the film can be a powerful magnet to generate tourism. These places can be differentiated from others through films. A small hotel such as The Crown Hotel at Amersham, England, successfully promotes the room used by Hugh Grant in 'Four Weddings and a Funeral'.

Websites that link particular films to their film locations is a very effective promotional tool to induce tourists to the destination (Croy and Walker, 2003). This promotion strategy has been used in New Zealand where Tourism New Zealand developed part of its website to specifically promote 'The Lord of the Rings' and other film locations throughout the country.

Other marketing strategies include guided film tours and film walks. These tours rely heavily on the illustrations from the films so that the tourists can recognize the real landscapes used in the film

One of the major economic benefits that film-induced tourism can bring to the local community as a result from the reviewed literature is enduring tourism receipts. Film locations can be all-year, all-weather attractions which alleviates problems of seasonality in the tourism industry (Beeton, 2005). Riley et al. (I998) studied I2 films and found that the peak of 
the interest appear after the release of the film, approximately 50\% increase in visitation at least five years later and the image is often retained for a long time.

Although films provide many positive impacts for the destination in terms of economic, cultural values and destination awareness and image, draw-backs of the film should also be carefully considered. This could be undesirable consequences such as loss of privacy and the difficulty of accessing local facilities for local people, traffic congestion and the destruction of the natural environment (Hudson and Ritchie, 2006). Another important issue includes the residents' attitudes towards the influx of film producing crews and the large number of tourists to the film locations.

\section{Serbia - A Potentional Film Tourism Destination}

Movies and tv series are great promoters of their country of origin. After Hispanic series, which increased interest in Spanish-speaking countries, the Turkish soap operas have opened doors to tourists. The number of tourists in Turkey, who come from 20 countries in which turkish series are emitted rose by a quarter. The question, then, is how serbian cinematography can contribute to a positive image of Serbia in the world. Serbian films are realistic, experts say, have a strong social moment, but it would be well to emphasize the modern image of our country also. Recent film which send brighter image of Serbia in the world was „Montevideo Bog te video“ („Montevideo God Bless You“) (http://www.rts.rs.)

Serbia's robust film industry has existed for over a century, reaching its peak in the I980s, when Yugoslavia was the second leading destination for international productions after the UK. This international success fostered a burgeoning industry complete with both a vast network of highly experienced and inspired film crews and artists and a strong infrastructure of studio stages and laboratories. In the past decade, Serbia's renowned film programs, which have produced a formidable pool of industry talent, have nurtured the domestic film industry. As a result, a number of film ventures created by Serbia's production companies have earned the recognition of some of the most prominent film festivals across Europe and the United States (http://www.filminserbia.com). Thanks also to Serbian artists who have achieved recognition at the international level, for example, famous film director Emir Kusturica, many projects have ben realized, and Hollywood filmmakers were better acquainted with our country and the opportunities it offers. Film in Serbia is emerging and the country is viewed as the new destination for international, feature, documentary and commercial film markets because it offers low production costs, highly skilled creative talent, scenic locations and a solid industry infrastructure.

In 2009 the Serbia Film Commission (SFC) was established which includes the leading producers of feature films, television, tv commercials and animation. The principal aim of the SFC is to promote and develop Serbia as a cost-effective, high-quality, competitive destination for international filmmaking, and to provide information and support to international filmmakers considering using Serbia for their productions. SFC is dedicated to fostering a film-friendly environment in the country and hosts the Film in Serbia website which has been specifically created to house detailed information on production and post-production (www.filminserbia.com) as well an expanded locations database (www.filmlocationserbia.com). 


\section{Conditions for shooting foreign films in Serbia}

Serbia offers a well-developed film industry infrastructure and a comprehensive set of production services. Production companies are highly accomplished, offering quality services at competitive costs and multilingual staff adept at shooting throughout the former Yugoslavia and have extensive international experience as well. Most have supported several international productions in Serbia and many have also worked directly with Hollywood-trained Serbian industry talents, including the costume designers for "Marie Antoinette“, the production designers for „Delicatessen“, „Heidi“, „Rasputin“ and the visual effects creators for „Pearl Harbor“, „Star Wars: Episode 2“, and most recently „The Reader“. The country’s production companies enjoy strong working partnerships with key industry players and counterparts across the Balkans, making Serbia the ideal hub for regional and international productions (http://www.filminserbia.com/ProductionServices.aspx).

Serbia offers a range of locations that represent many of the best location sites in the Balkans. Due to its strategic location between European East and West, Serbia features a wide range of architectural styles, from Habsburg to Socialist period structures and from Roman and Medieval to contemporary urban. Serbia possess an array of historical and cultural sites. They include exquisite Romanesque-Byzantine monasteries and churches, Roman and post-Roman era fortresses and castles, scenic vineyards, bucolic villages and magnificent villas (http://www.filminserbia.com/Locations.aspx).

For example, the film „Around the World in 80 Days” - filmed in and around Serbia in I989 and starring Pierce Brosnan - represented a total of I8 countries, with Belgrade alone representing 7 world cities. Serbia so far has represented in film western and central European cities and regions, medieval fortresses, the English countryside, ancient Roman towns, communist Soviet-era countries, a World War II concentration camp, Afghanistan and Turkey (www.filmlocationserbia.com ).

The film production industry has experienced a revival in recent years. As foreign productions have increasingly looked to Eastern Europe as a film location, Serbia's competitive advantages have been rediscovered. As a result, several international films were produced in Serbia in recent years (Table 2).

Besides money, this kind of projects bring immeasurable experience to domestic filmmakers, film infrastructure is strengthened, the government collects taxes, but also gets free advertising in the world. For, where the famous actors are, there are also journalists. While Ralph Fiennes filmed in Serbia, about 300 articles were published in the world media and in almost every interview he answered to question why he chosed to shoot film „Coriolanus“ in Belgrade (http://www.novosti.rs/vesti/kultura). Therefore, the existence of dedicated units in national tourism organisations, local authorities and local tourism agencies to facilitate both filming and film tourism is desired because of the importance placed on the power of film and TV in generating visits to locations. 
Table 2. Several Foreign films produced in Serbia 2005-2013

\begin{tabular}{|l|}
\hline IN PRODUCTION \\
\hline The Tenor - Lirico Spinto (2013), directed by Sangman Kim \\
\hline Ironclad: Battle for Blood (2013), directed by Jonathan English \\
\hline Trilogia anni '70 (2013), directed by Graziano Diana \\
\hline COMPLETED \\
\hline Therese Raquin (2013), directed by Charlie Stratton \\
\hline Titanic: Blood \& Steel (2012), directed by Ciaron Donnelly \\
\hline Chernobyl Diaries (2012), directed by Oren Peli \\
\hline L'ultimo papa re (2012) directed by Luca Manfredi \\
\hline Lock Out (2011), directed by James Mather and Stephan St. Leger \\
\hline The Raven (2011), directed by James Teigue \\
\hline The Other Guys (2010), directed by Adam MacCay \\
\hline Il Restauratore (2010), RAI Fiction TV series \\
\hline Coriolanus (2010), directed by Ralph Fiennes \\
\hline The Big Picture (2009), directed by Eric Lartigau \\
\hline Human Zoo (2009), directed by Rie Rasmussen \\
\hline District 13 Ultimatum (2008), produced by Luc Besson \\
\hline The Brothers Bloom (2007), directed by Rian Johnson \\
\hline Einstein (2007), directed by Liliana Cavani \\
\hline Hotel Meina (2007), directed by Carlo Lizzani \\
\hline Caravaggio (2006), directed by Angelo Longoni \\
\hline I Figli Strappati (2005), directed by Massiomo Spano \\
\hline Fade to Black (2005), directed by Oliver Parker \\
\hline
\end{tabular}

Source: http://www.filminserbia.com/MadelnSerbia.aspx

\section{Drawbacks in development of foreign fim productions in Serbia}

Serbia has decided to compete more effectively with its European neighbours by launching a new filming incentive in $201 \mathrm{I}$ worth up to $15 \%$. The cash rebate was valid for feature films, $\mathrm{TV}$ and documentaries that spend at least 2.000.000 $€$ in Serbia. It was a year-long pilot scheme and wasn't renewed for 20I2, but a new $20 \%$ rebate is ecpected to be available from 2OI3. The new incentive scheme could prove an attractive offer for production companies around the world (http://www.thelocationguide.com). Law on Cinematography, which was adopted in 2OI2, predicts four secondary legislation for the adoption one of which is the regulation on incentives. Due to delays in the adoption of the regulation on encouraging foreign film work in Serbia, country in the past three years has lost about Ioo million euros. This assessment is presented by Serbian Film Commission.

Thirty countries in the world and 44 states in the USA have and very aggressively promote incentives for foreign film projects. These incentives range of 15 to 45 percent of the funds spent in the state in which the recording is taking place. Calculations because of which they decided on something like that shows that for every dollar spent on production, in the local economy remains 2.5 dollars. While shooting the film comes to the big employment of 
filmmakers, but also auxiliary workforce (caterers, transportation, handicrafts, etc.), small and medium-sized enterprises are getting jobs, and the state has a direct income from taxes.

Models of incentives ranging from tax credits (writing off part of taxes), over the return of part of the invested funds, to grantees. Among the neighboring countries, Hungary opted for a tax credit of $2 \mathrm{O}$ to 25 percent, Croatia uses model of $2 \mathrm{O}$ percent return on resources, and Macedonia plans in 2013 to implement Hungarian model, while Romania and Bulgaria are without incentives. How important are the incentives for the film industry is quite well illustrated by example that Hungary tookover 80 percent of productions from Czech Republic, which until 2004 had 270 million dollars a year from the shooting of foreign films. New York City for only four years since the introduction of incentives earned seven billion dollars. According to data from the SFC, Serbia from foreign film and TV productions in 2007 had an income of 3 million euros, in 2008 it doubled to 6 million, next year IO million euros, in 2010 it earned 2I million euros, while in 2OII, these revenues decreased to 8.5 million In Serbia, annualy is achieved over 3.00O overnights thanks to this industry (http://www.vesti-online.com).

Table 3. Serbia/Hungary cost-comparisson (in \$US)

\begin{tabular}{|c|c|c|}
\hline Budget Line Item & Serbia & Hungary \\
\hline PRODUCTION STAFF & $1,118,561$ & $1,416,070$ \\
\hline EXTRA TALENT & 140,916 & 271,185 \\
\hline SET DESIGN & 405,467 & 449,821 \\
\hline SET CONSTRUCTION \& STRIKING & 989,919 & $1,864,452$ \\
\hline STRIKE & / & 115,895 \\
\hline SET OPERATIONS & 408,362 & 494,673 \\
\hline SPECIAL EFFECTS & 596,270 & $1,184,528$ \\
\hline SET DRESSING & 556,688 & 643,211 \\
\hline PROPERTY & 264,182 & 317,781 \\
\hline PICTURE VEHICLES \& ANIMALS & 400,463 & 742,428 \\
\hline WARDROBE & 445,862 & 743,786 \\
\hline MAKEUP \& HAIRDRESSING & 156,864 & 117,061 \\
\hline LIGHTING & 491,415 & 511,008 \\
\hline CAMERA \& VIDEO & 830,467 & $1,044,931$ \\
\hline SOUND & 92,157 & 177,013 \\
\hline TRANSPORTATION & 637,172 & 761,768 \\
\hline LOCATIONS & $1,100,856$ & $1,488,925$ \\
\hline FILM \& LAB & 514,096 & 557,638 \\
\hline STAGE / FACILITIES EXPENSES & 388,528 & 852,340 \\
\hline ANIMALS & I & 12,802 \\
\hline SECOND UNIT & 651,615 & $1,038,240$ \\
\hline SPLINTER UNIT & 76,847 & 91,740 \\
\hline AERIAL UNIT & 474,795 & 474,795 \\
\hline MARINE UNIT & 911,753 & 911,753 \\
\hline FRINGES & 688,271 & 789,366 \\
\hline TOTAL & $12,341,526$ & $17,073,210$ \\
\hline SAVINGS IN SERBIA: & $4,731,684$ & \\
\hline
\end{tabular}

Source: Serbia Production Guide, 2012. 
Before 2OII Serbia represented some of the lowest labor and production costs in the region. Filming in Serbia costed approximately I5-20\% less than in Romania, 20\% less than in Hungary and 40\% less than the Czech Republic. Much of this was based on labor, with high quality construction and design services available at a much lower cost than in neighboring countries. The following is a line-item-by-line-item budget comparison of below-theline costs between Serbia and Hungary for an actual project, which shows that the same project in Serbia saved $27 \%$ of total costs (Table 3 ).

Until 2OII cost savings on an international scale in Serbia were evident. First line of the Table 3 below shows the comparative budget of the same mid-level film shot in several different territories. Second line compares Belgrade to other locations and demonstrates that it was $37 \%$ cheaper to produce the same film in Serbia than it would be in Los Angeles, and approximately $35 \%$ less than in London.

In recent years competitors from the neighboring countries overtook Serbia by offering better conditions. On the forefront is Budapest with an average 90 million euros per year. Since the Czech Republic two years ago introduced a system of incentives, Prague earns around 50 million euros of "film money“, what is the amont Serbia earned in five years although it has a much larger capacity. In 2OII in Kragujevac was filmed miniseries „Titanic: Blood and Steel“. This production entailed a I5 weeks shooting, I2 of which should be in Serbia and three in Ireland. But, as Ireland had better stimulations, producers remained in Serbia only five weeks. For the same reasons instead of in Serbia, „Die Hard 5“ was filmed in Hungary, and the crew for te sequel of blockbuster „300“ selected Bulgaria. Producers do not have the patience nor are emotional and will quickly go away if we do not have what to offer them (http://www.novosti.rs/vesti/kultura).

Table 4. Comparative budget in different countries until 2011

\begin{tabular}{|r|r|r|r|r|r|r|r|r|}
\hline & Los Angeles & Vancouver & \multicolumn{1}{c|}{ Sidney } & \multicolumn{1}{c|}{ Berlin } & \multicolumn{1}{l|}{ Budapest } & \multicolumn{1}{l|}{ Prague } & \multicolumn{1}{l|}{ London } & \multicolumn{1}{l|}{ Belgrade } \\
\hline Cost \$US million & $\$ 22.2$ & $\$ 22.6$ & $\$ 21.7$ & $\$ 22.1$ & $\$ 17.2$ & $\$ 17.4$ & $\$ 21.5$ & $\$ 14.0$ \\
\hline Serbia \% less & $-37 \%$ & $-38 \%$ & $-35 \%$ & $-36 \%$ & $-18.6 \%$ & $-19.5 \%$ & $-35 \%$ & $\$ 14.0$ \\
\hline
\end{tabular}

Source: www. filmlocationserbia.com

Serbia is nevertheless still competitive due to a variety of locations, financial benefits, and a very good supporting crews, which is especially good reference. Hollywood studio „Universal“ decided, that the film „Tesla, the ruler of the world“ is goning to be filmed in Serbia, despite the original idea that shotting will take place in the UK. The film won the support of the American and Serbian government, with financial and marketing support of „Universal“ (http://www.rts.rs.). In the film tourism business, there is little investment but the profit is high. Only from one film Serbia could get up to 20 million dollars, without any investment. For Serbia are interested some major Hollywood studios, but they are hard to keep when they see that they may have no insentives and can not even get certain locations (http://www.b92. net/kultura).

There is no established system when the permits for recording are in question. Someone is willing to cooperate, and someone is not. What kind of relation does the state have for this business speaks the fact that four years ago Serbia had no association to deal seriously with the promotion of sites in Serbia, until the USAID in one analysis estimated that Serbia can be competitive in this field when compared to others. Thus, the Serbian Film Commission started working on the promotion, which is obviously having some success, as well as in suggesting what the state could do to attract foreign filmmakers (http://www.vesti-online.com ). 


\section{Conclusions}

This paper provides an enlightening view of film-induced tourism and it further reveals the benefits of film-induced tourism in promoting locations.

Movies systematically function as a mean of escape from the everyday routine and this characteristic is in common with tourism. Films develop characters, while an advertising tourist spot tries to pass a message. The difference in the sentimental memory of spectator is very important. A spot can be shown many times during a period, however after the campaign it rarely remains in the spectator's memory. In contrast, the cinematographic film has long-lasting effect because it approaches the spectator satisfying his sentimental or ideological concerns (Vagionis and Loumioti, 2OII).

An increasing number of countries and regions have started to compete in attracting film productions (including Serbia) by offering considerable tax rebates. In return, more and more production companies agree to provide marketing material for promoting the portrayed destinations (www.northseascreen.eu).

In recent years Serbia is no longer best low-budget film destination in the region (due to financial incentives), and that was its main asset. If new incentive program is not promptly introduced, it will be fully left behind. Serbia has a huge benefit in the arriving of foreign film crews, because it is an investment of several million euros in just a few weeks. During shooting, foreigners stay in hotels, eat at restaurants, go out in cafes, visit the city and enjoy the numerous other services. Production leaves money also to local municipalities, state institutions or individuals whose locations are rented for the film (http://www.novosti. rs/vesti/kultura).

Film tourism (world-wide, as well in Serbia) has tremendous potential. It is, however, a specific marketing niche that needs to be understood. Only by investing the necessary resources as well as establishing sustainable strategies can destinations profit from it in the long run.

\section{References}

Beeton, S. (2005). Film-Induced Tourism. Clevedon, UK: Channel View Publications.

Busby, G. and Klug, J. (2OOI). Movie Induces Tourism: the Challenges of Measurement and other issues. Journal of Vacation Marketing, 7, 316-332.

Carl, D., Kindon, S. and Smith, K. (2007). Tourists' Experiences of Film Locations: New Zealand as 'Middle earth'. Tourism Geographies 9 (I), 49-63.

Croy, W.G. and Walker, R.D. (2003). Rural tourism and film: Issues for strategic regional development. In D. Hall, L. Roberts and M. Mitchell (Eds.), New Directions in Rural Tourism, UK: Ashgate Publishing Ltd.

Horrigan, D. (2009). Branded content: A new model for driving tourism via film and branding strategies. Tourismos, 4, 3, 5I-65.

Hudson, S. and Ritchie, B. (2006). Promoting Destinations via Film Tourism: An Empirical Identification of Supporting Marketing Initiatives. Journal of Travel Research, 44, 387-396. Iwashita, C. (2003). edia Construction of Britain as a Destination for Japanese Tourists: Social Constructionism and Tourism. Tourism and Hospitality Research, 4, I29-I43.

Kim, S. S., Agusa, J., Lee, H. and Chon, K. (2008). Effects of Korean television dramas on the flow of Japanese tourists. Tourism Management, 28(5), I34O-I353. 
Kim, H. and Richarson, S. (2OO3). Motion picture impacts on destination images. Annals of Tourism Research, 3O(I), 2I6-237.

Macionis, N. and Sparks, B. (2006). Film Induced Tourism: An Incidental Experience. International Tourism and Media Conference, Melbourne, Australia.

Macionis, N. (2OO4). Understanding the Film-Induced Tourist. In W. Frost, G. Croy and S. Beeton (Eds.) International Tourism and Media Conference Proceedings, 86-97, Melbourne: Tourism Research Unit, Monash University.

Rewtrakunphaiboon, W. (2009). Film-Induced Tourism: Inventing a Vacation to a Location. BU Academic Review 8, 33-42.

Riley, R., Baker, D. and Van Doren, C. (1998). Movie-induced tourism. Annals of Tourism Research, 25, 919-935.

Serbia Production Guide (2OI2). Belgrade: Serbia Film Comission.

Schofield, P. (1996). Cinematographic Images of a City. Tourism Management, I7 (5), 333-4O.

Vagionis, N. and Loumioti, M. (2OII). Movies as a Tool of Modern Tourist Marketing. Tourismos, 6, 2, 353-362.

http://www.b92.net/kultura/multimedija.php?nav_id=668696

http://www.filminserbia.com/AboutUs.aspx

http://www.filminserbia.com/Locations.aspx

http://www.filminserbia.com/ProductionCompanies.aspx

http://www.filminserbia.com/ProductionServices.aspx

http://www.filmlocationserbia.com/upload/document/production_guide_2OI2.pdf http://www.northseascreen.eu/File/I2O7_-_Filmtourism_Handbook_UK_single_I.pdf http://www.novosti.rs/vesti/kultura.7I.html:39I859-Svetske-filmadzije-zaobilaze-Srbiju http://www.nytimes.com/2OI2/II/24/business/media/new-zealand-wants-a-hollywoodput-on-its-map.html? pagewanted=all\&_r=O http://www.rts.rs/page/stories/sr/story/I25/Dru\%C5\%AItvo/IOI2436/Filmski+turizam.html http://www.rts.rs/page/magazine/sr/story/4II/Film/I20824O/Holivud+izabrao+\%E2\%

80\%93+\%E2\%80\%9ETesla\%E2\%80\%9C+se+snima+u+Srbiji!.html http://www.thelocationguide.com/blog/2OII/O3/serbia-launches-I5-film-incentive/ http://www.vesti-online.com/Vesti/Srbija/I73654/Srbiji-od-Holivuda-2O-miliona-dolara 